\title{
Antithesis and argument in the hymns of Ephrem the Syrian
}

\author{
PJ Botha
}

\begin{abstract}
Antithesis and argument in the hymns of Ephrem the Syrian

This paper reflects research on the semantic structure of antitheses. The thesis being proposed is that the defining quality of antitheses was implemented by the Syrian church father Ephrem as a rhetoric technique to enhance the power of arguments in his hymns. Examples are being investigated to explain the function of antitheses in the surface structure of some of his arguments.
\end{abstract}

The title of this paper presupposes a certain knowledge of at least three different fields of study, namely rhetoric, reception criticism and Syriac hymnology. Combining these subjects may seem to be like pouring new wine into old wineskins, but I nevertheless hope that the folly can be pardoned in the light of the many antitheses in the hymns of the Syrian church father, Ephrem, coupled with the strong polemical tenor of his work.

\section{ANTITHESIS}

According to Lausberg (1960: 389) 'das Antitheton ist die Gegenüberstellung zweier inhaltlich gegenzätzlicher res'. The contrast can be constructed with the help of single words, groups of words or sentences. Lausberg (1960: 390) in addition stresses the characteristic that the two parts of an antithesis are also in accordance with one another, so that outer similarity and inner contrast become functional: 'die äussere Gleichheit ist selbst ein Kontrast gegenüber der Gegensātzlichkeit der gedanklichen Inhalts'.

These two characteristics of the antithesis, namely contrast and accordance, are found more than once in more recent definitions. According to Krašovec the similarity of the two parts of an antithesis is of great importance to demarcate antithesis and merism as separate figures of speech. He (Krašovec 1984: 5) describes it in this way: 'The fundamental trait of the antithesis is that two opposing elements 
exclude each other in relation to a common idea...' while 'In a merism the opposite do not serve to create a contrast of thought but a unity of thought - totality'.

The elements of contrast and accordance found in the definition of Lausberg thus also figure here. And yet it is clear that Lausberg's definition has undergone a subtle change. The 'similarity of the parts' and the 'outer similarity' he spoke about, are expanded by Krašovec to 'a common idea'. The difference and the similarity are not restricted to the formal aspects, but relate also to the substance of the matter. On account of this definition, it may be a workable representation to compare an antithesis with the two poles of a horseshoe magnet, while a merism can be compared to the ends of a straight rod of steel. The characteristic of tension between two comparable poles should thus be seen as an important criterion when identifying an antithesis.

To relate the theoretical description of antitheses to other areas of study, it is subsequently necessary to describe the antithesis semantically. The following may be proposed as a point of departure:

- The two poles of an antithesis stand in a paradigmatic relation. That is to say, they are interchangeable within the same context and therefore relate to the same semantic field. This characteristic may be compared with the 'similarity' Lausberg has emphasised and the 'common idea' in the definition of Krašovec.

- The two poles are not the same, but differ in certain aspects so as to be diametrically opposed. Semantically spoken, that means that they fall under the same archilexeme, having some common semes but being mutually exclusive with regard to some other semes. For example the antithesis in Psalms 1:6:

'For the Lord watches over all the plans and paths of godly men, but the path of the godless lead to doom'.

godley men

godless

$\begin{array}{cccc}\text { s1 } & \text { s2 } & \text { s3 } & \text { s4 } \\ + & + & + & - \\ + & + & - & +\end{array}$
$\left.\begin{array}{l}\mathrm{s} 1=\text { describes a group of people } \\ \mathrm{s} 2=\text { religious term }\end{array}\right\}$ common semes $=>$ Archilexeme

s3 = describes someone who honours God $\mathrm{s} 4=$ describes someone who does not honour God semes

- The contraposition of the two poles brings about a semantic and semiotic tension. Two neutral words are momentarily changed to 
extremes within a micro-context. This happens because not all the designata of the two terms can operate within the micro-context and some are consequently disregarded. The implied attributes are limited causing certain semiotic modifications. Contrasting certain words or phrases within an antithesis thus causes a particularising process, similar to the process occurring in metaphors (cf Pelc 1971: 182).

\section{RECEPTION CRITICISM AND ANTITHESES}

Reception criticism concerns itself with the effect of literary art on the reader or listener. Apart from the productive plane of aesthetic experience (poesis) and the receptive plane (aesthesis), there must also be distinguished a communicative plane of aesthetic experience, called katharsis. According to Jauss (1982: 92), this third aspect of aesthetics is .... the enjoyment of affects as stirred by speech or poetry which can bring about both a change in belief and the liberation of his mind in the listener or spectator'.

Krašovec (1984: 140) states that antithetical structure has both a unifying and a disconnecting function. According to him (Krašovec 1984: 140), the use of antitheses results in a better delimitation and surer perception of the meaning of individual elements such as terms, phrases and images, in themselves as well as of their function within the complete antithetical structure.

The antithesis is regarded as an emphatic figure of speech par excellence. According to Haefeli (1932: 8), emphatic figures of speech are meant to underline, to give prominence to, to emphasise and to exert a continuous influence in the mind of the hearer. Put in another way, it may be said that an antithesis is a kind of double hyperbole, an over-emphasis of contrast to effect a purpose within the reader or listener. To determine that effect, the text containing the antithesis should be analysed carefully with regard to structure and style.

I should like to propose that antitheses can be used as a powerful aid to certain arguments when used in contexts that have an argumentative character. If the logic or quasi-logic of the argument coincides with the antithesis, the antithesis itself can be said to possess argumentative value. 


\section{ARGUMENTS}

There is a reasonable measure of agreement that Aristotle was correct in describing an argument as a reduced form of a proof (Ars Rhetorica 95b, 96a). According to him, a proof is the form of an argument in which all the steps are explicitly executed.

There is a difference of opinion, however, on the way in which a logical or mathematical proof is reduced to an argument. Ingrid and Werner Kummer (1976: 83-105) have tried to prove that the surface structure of any argument presupposes a base structure in which a logical argumentation can be identified. By way of deleting axioms and postulates which can be assumed to be obvious or are accepted by the audience, and by making permutations in the sequence of axioms, postulates and conclusions, a more simple surface structure can be created. According to them, the base structure of an argument can thus be regained by expanding the surface structure.

Over against this view, the point of departure of Chaim Perelman (1979: 18) is that non-formal arguments do not consist of a chain of ideas of which some are derived from others according to accepted rules of inference, but rather of a web formed from all the arguments and all the reasons that combine to achieve the desired result. According to him, there is a difference of paramount importance between an argument and a formal proof because arguments are conducted in natural language, not the artificial language employed in calculus (Perelman 1979: 19). The truth of this becomes clear when one considers the fact that each symbol used in mathematical language has but one designatum. Since there is no comparable formalisation in natural language, an argument can never be a proof.

From a semantic point of view, one is inclined to remark that context is of great help in selecting but one denotation for a certain term. But Perelman (1979: 19) cites examples such as 'business is business' to demonstrate that tautology, which is an important element of logical language, is not part of natural language. When one says 'boys will be boys' the listener looks for different plausible interpretations of the same term that will render the whole statement both meaningful and acceptable. It follows that semiotics is of far greater importance in natural language and therefore in the construction of an argument than it is in calculus.

It is through this characteristic of natural language that the semantic and semiotic structure of antitheses can be of importance in constructing an argument. Since the contraposition of two important elements of 
an utterance in antithetical form can contribute to a more precise definition of the semantic content of the terms (cf Aristotle, Ars Rhetorica 18b), the use of an antithesis in an argument can contribute largely to its logical or quasi-logical substructure. An antithesis can in effect be a good imitation of a logical proposition or axiom.

But since the proof of the text is in the reading, it is time to turn our attention to Ephrem the Syrian.

\section{EPHREM THE SYRIAN}

By way of introduction it should be mentioned that Ephrem lived and worked in Nisibis and Edessa during the fourth century (306-373 AD). $\mathrm{He}$ is regarded as one of the most important writers amongst the Syrian church fathers. He influenced the genre of the church-hymn decisively, making a great contribution through a form that later became the cornerstone of the Kontakion as Christian hymn in the Greek-speaking world.

The use of lyrics by Ephrem was, however, already a reaction to hymns existing before his time. The Gnostical sects had begun to use hymns as an antipode against the Psalms of the Old Testament, which was not acceptable to them. The use of non-biblical hymns in a Christian setting came to be associated almost exclusively with Gnosticism (cf Barkhuizen 1985: 4). In reaction to this, the church at first rejected all hymns of non-biblical origin, but later began to counter the Gnostic influence by propagating hymns with the same metrical and musical pattern as those used by them, containing an 'orthodox' dogma (Barkhuizen 1985: 4). It was in this tradition that Ephrem became one of the fore-runners. He did not employ poetics primarily for aesthetical purposes, but for the sake of argument (Bardenhewer 1962: 343).

Ephrem had a masterly command of antitheses. Different types of qualitative, quantitative and generic antitheses which are constructed by antonyms and other types of semantic opposites, abound in his work. They not only serve to create a certain atmosphere, but also to exert a lasting influence in the mind of the listener or singer.

\section{ANTITHESES AND ARGUMENTS}

\subsection{Jonah - an argument from a precedence case that regulates present action}

In a metrical sermon on the story of Jonah, Ephrem described the conversion of the citizens of Nineveh: 
85. Everyone sowed compassion to reap salvation from it.

To Jonah the sinners listened and everyone confessed his sins.

The hateful city listened to him and quickly discarded her hatefulness.

Even the masters listened to him they called out release for the oppressed.

The slaves gave him a hearing in a just way and honoured their masters even more.

On the voice of Jonah, noble women humiliated their pride through the penintential robe.

This description is followed by an application to the congregation:

There was true penance

because even haughty women clothed themselves in humility.

In comparison with that penance ours is but like a dream.

And in comparison with that weeping ours is only a shadow.

And in comparison with that humiliation ours is but a phantom of humiliation.

There is but few that have forgiven trespasses in this fast of ours.

The Ninevites gave alms

May we at least set the oppressed free from their lament.

The Ninevites set slaves free Have you but compassion on the free-born!

The audience is well demarcated by means of an authorical monologue (cf Barkhuizen 1986: 19). It is the contemporary Christians ('us', 'this', 'you'). The message that is meant to be received through the events in Nineveh is also' clearly formulated: The author argues that the total repentance of a heathen city, since having listened to the word of a single prophet imposes a moral duty upon Christians to do likewise when called upon. The argument can be described as a minori ad maiorem: If the word of a single prophet caused such a reaction amongst 
heathen people, the more so can one expect Christians (who have received the complete Scriptures) to show compassion in lesser things.

The use of an antithetical structure thus coincides fully with the progress of the argument in this instance:

\#1 State of affairs A :: State of affairs B \} Complete repentance in Nineveh

\#2 Complete repentance then :: Lack of repentance now \} You should repent!

The antithetical structure operates on two levels. The conclusion that arises from the clear antithetical description in the first instance is itself incorporated into the second set of antitheses, thereby creating the impression of a logical, step by step progress of argumentation.

\subsection{The inadequate cult - an argument from the interests of the agents}

Ephrem's polemics were directed especially against the Jews of his time. In the cycle of Passover hymns (De Azymis, De Crucifixione and De Resurrectione), the purpose of the polemic can probably be best described as an endeavour to prevent Christians from being converted to Judaism rather than the opposite, attempting to convert Jews. This can be deduced not only from the observation that these hymns were meant for liturgical use by Christians, but also from the general tenor of the hymns themselves. Ephrem's predecessor Afrahat has displayed great self-control, respect for his opponents and a total lack of anti-Semitism in his polemics (Neusner 1971: 5). The same can not be said of Ephrem's hymns which reveal a bitter enmity against the Jews (Segal 1970: 101). He even calls the Jewish people 'a swine' (Az XIX 27) and describes them as 'murderers' of God's Son (Cruc V).

It soon becomes clear that the immediate purpose of these hymns was to deter Christians from participating in Jewish practices such as the eating of unleavened bread. This means that the Jews must have posed a threat to the Christians. Material from other sources confirms this surmise. The church in Nisibis (Neusner 1971: 4) and that in Edessa (Duncan 1945: 21) included large numbers of converted Jews during the fourth century. Conversions of Jews to Christianity upset the rabbis (Neusner 1968: 11) and there certainly was no less danger that the opposite could happen. It is known that Christians in Nisibis continued 
the practice of using unleavened bread at Passover (Segal 1970: 100). Ephrem opposed this custom with great zeal, arguing that Christians who ate unleavened bread, ran the risk of falling into disbelief just like the Jews ( $A z$ XVIII 13).

The core of all anti-Jewish polemics all along the line of the church fathers is the thesis about the rejecion of Israel (Hruby 1971: 27). This is also true of Ephrem. The Jews were rejected by God through their own fault. The reverse of the medal is of course the doctrine about the election of the church.

The elaboration of this dogma, which I should like to call the doctrine of substitution, causes the two groups, Christians and Jews, to be continually counterbalanced. The old dispensation was concluded with the advent of Christ, and together with the old dispensation, the Jewish people were thought to have been terminated (cf $A z$ XIX refrain). According to Hruby (1971: 27), it was precisely the empirical observation that the Jews did not cease to exist, or to renounce their religious claims, that compelled the church fathers to polemicise against them and describe them as an abgetane Grösse.

Several characteristics attributed to Christianity even before the time of Ephrem, gave rise to a polar style in the anti-Jewish polemics. Amongst other things, opposing pairs of ideas such as Old Testament:: New Testament, Particularism :: Universalism, Type :: Antitype, et cetera, can be mentioned. Ephrem availed himself of the opportunity to exploit these pairs of opposites in antithetical style. The Jews of his own time who persisted in Judaism, in his view identified themselves with the rejection of Christ and therefore revealed the same religious conviction as those Jews who rejected their Messiah. In a corporate way they therefore shared in the guilt of crucifying Christ. In their negative attitude against God and his anointed - and therefore against Christians, they were tied together in an unholy covenant (Cruc IV 7,8 ). Judaism is portrayed by Ephrem as exclusivistic and self-centred.

Over against this, Christianity is seen to be universalistic - salvation is meant for the 'peoples' in contradistinction to the rejected people of God from the Old Testament. The church that grew from the many peoples displays a solidarity since it has formed a distinctive cultural group. It can be compared in all its facets to the Jewish people, but it surpasses that people in being founded upon a new doctrine of salvation and consequently also opposes that people.

The ideas about the rejection of the Jews and the election of Christians go hand in hand and form what can be called a doctrine of 
substitution. All polarisation of these two groups of people in Ephrem's hymns on Easter can be reduced to this basic idea.

In one of his hymns about the last supper (De Azymis II), Ephrem says the following:

4. Priests, who were better than animals, slaughtered and brought sacrifices of animals. The priest was sanctified through a lamb that was not holy.

5. There is no lamb elevated above the lamb from above. Since the priests were wordly and the lamb was heavenly, He became sacrifice and sacrificer to himself.

6. For the priests were, because of their shortcomings, not fit to sacrifice the lamb without defect. He became a peace-offering and through his blood, which brought peace for everything, He brought peace for that which is above and that which is below.

10. The kingship of David's lineage eagerly awaited the son of David.

It saw Him and was pleased, and Zion received the glad tidings.

She saw Him and became sad over the beauty that pleased all.

11. 'A prophet' the people called him that was the Lord of prophesy.

Their honour was a dishonour: they held him on the other hand for an 'errant person'.

Their honour was pretence; their blasphemy was real.

All these contrasts have the cumulative effect of establishing a line of tension between the different poles. The extremes are emphasised and the connotations highlighted with a resultant degradation of the negative aspects and a strengthening of the positive poles. The antithetical contrasting and resultant effect can be summed up as follows:

\#1 Priests :: Sacrificial lamb (unholy) \} Insufficient cult

\#2 Priests (earthly) :: Lamb (heavenly) \} Insufficient cult

\#3 Priests (defective) :: Lamb (without defect) \} Insufficient cult

\#4 Kingship (glad) :: Zion (sad) \} Wrong inclination

\#5 People (honour Christ) :: People (blaspheme Christ) \} Wrong inclination

Through this process, the insufficient cult is linked closely with the deficient people. The use of antitheses in this hymn cannot be said to 
emphasise any of the opposing poles more than it serves to stress the semiotic conclusion that the people of the cult has become obsolete. In this way, antitheses strengthen the argument.

5.3 The dangers of unleavened bread: An argument based on the results and consequences of action

The eighteenth hymn in the cycle De Azymis is quoted in full:

On the same tune

1. The peoples ate unleavened bread during the Passover; through the stale food, their inner life was renewed.

Refrain: Thanks to the Son who gave his body to us in place of that unleavened bread $\mathrm{He}$ gave to the people.

2. Man should not renew his food; he should renew his heart.

3. For behold, in Nisan also does graze the butting bull on new pasture.

4. And the people, while they were eating unleavened bread also gored the Son with a spear.

5. Further: The wild donkey grows fat on new pasture like him the people grew fat and kicked.

6. If it were profitable to eat new food, the animal would be better than that people.

7. Also in this (the animal) is better than him: Through the animal they are ridiculed that they do not, like it does, know their Master.

8. The snake also casts off (its skin), also renews itself; no matter how much it casts off on the outside, it becomes old on the inside.

9. Behold: Outwardly the people replaces its garment; but on the inside the deadly poison remains undisturbed.

10. For it resembles the snake - that first one which cunningly gave us the fruit of death.

11. For behold: He gives us of his unleavened bread, so that it can become a deadly poison in us.

12. Woe to the people that has become old, that wants to make the new ones old as with yeast. 
13. Woe to the unleavened bread that is step by step drawing those that eat of it closer to the unbelievers.

14. Mixed with the new unleavened bread (the people) yields the old yeast of the heathendom.

15. The symbol of the Son Moses has concealed in that unleave ned bread as a sustenance.

16. He (Jesus) washed away the unleavened from the sustenance and gave it to Judas as a poison.

17. The poison of Iscariot one thus takes from that unleavened bread.

The purpose of this hymn was to discourage Christians to eat unleavened bread at Passover. To attain this purpose, Ephrem made use of several arguments. The surface structure of the arguments can be represented as follows:

\section{Argument}

Antitheses

1 Unnecessary to eat unleavened bread

$\mathrm{A}:: \mathrm{B} \rightarrow \mathrm{C} \quad \cdots$

Refrain: Christians have received something better

$\mathrm{D}:: \mathrm{E}->\mathrm{F}$

2

Of no avail on the inside

$\mathrm{G}:: \mathrm{H}->\mathrm{I}$

37

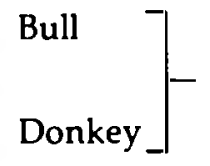

Negative result

$\left.\begin{array}{l}5 \\ 6\end{array}\right]$

7

Scriptural proof

$$
\mathrm{J}:: \mathrm{K}->\mathrm{L}
$$

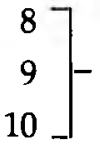

Snake

$$
\mathrm{M}:: \mathrm{N}->\mathrm{O} \text {. }
$$

Evil result

Strategy of the people

$$
\mathrm{P}:: \mathrm{Q}-\mathrm{R} \quad \cdots
$$

$\left.\begin{array}{l}15 \\ 16 \\ 17\end{array}\right]$

Sustenance becomes a poison

$$
S:: T->U
$$

$V:: W->X$ 
$A=$ Preserved bread (=stale food)

$M=$ Renewed (=outside)

$\mathrm{B}=$ Passover (=renewed on the inside)

$\mathbf{N}=$ Aged (=inside)

$C=$ Unnecessary

$\mathrm{O}=$ No effect

$\mathrm{D}=$ Body (=us)

$P=$ New (=unleavened)

$E=$ Unleavened bread (=the people)

$Q=$ Old (=yeast)

$F=$ Received something better

$\mathbf{R}=$ Dangerous

$\mathrm{G}=$ Food

$\mathrm{S}=$ Sustenance

$\mathrm{H}=$ Inside

$\mathrm{T}=$ Poison

I = To no avail

$\mathbf{U}=$ Dangerous

$\mathrm{J}=$ Animal

$\mathrm{V}=$ Sustenance

$\mathrm{K}=$ People

$\mathrm{L}=$ Animal better than people

$\mathrm{W}=$ Poison

$\mathbf{X}=$ Dangerous

A conspicuous characteristic of the use of antitheses in this hymn is the incidence of double antitheses. It occurs in the construction 'A stands over against $B$ as $C$ stands over against $D^{\prime}$. For example in the first verse: Leavened bread stands over against the Passover as stale food stands over against inner renewal. In this way, an associative connection is formed: The reader or listener may agree fully with the first antithetical proposition and is carried along by the power of the double antithesis to accept also the second proposition. No one would question the fact that non-Jews ate unleavened bread during the Passover in which Jesus was crucified. But that they were renewed spiritually by doing so does not sound like the pure truth.

The argument in verse 8 and 9 is on the same level. That a snake is getting older despite the fact that it replaces its skin several times during its lifetime is common knowledge. But that the Jews are still carrying poison in their insides when they dress themselves with festive garments is not proven easily. The parallel antithesis implies this and a further implicit parallel between the Jews and the snake mentioned in Genesis 3 strenghtens this argument.

From these examples it becomes clear that Perelman was correct when he said that an argument is a web of accepted axioms to which certain propositions are linked by means of a process of association. When different propositions from the same argument are compared, they may even seem to be illogical. Ephrem has argued in this hymn that food has no effect on the spritual life of a person, but at the same time he is trying to prove that unleavened bread can be dangerous for one's spiritual life! 
5.4 The unpermissible Passover - an argument based on norms and rules regulating action

In the twenty-first hymn of the cycle De Azymis, Ephrem polemicises against the custom of the Jews to celebrate the feast of Passover. In verses 3 to 9 , a step by step explanation is given why Moses (i e the Torah) does not permit their doing so: The feast was accompanied by sacrifices and those were only allowed in the temple in Jerusalem. This is probably an allusion to Deuteronomy 12: 27 . If sacrifices were forbidden everywhere inside the Holy Land except in Jerusalem, how much more would it have been prohibited in the diaspora outside the Holy Land?

2. The feast about which was ordered that it should be celebrated in Zion,

behold, it is celebrated everywhere as if it doesn't matter.

3. For Moses did not allow the people to celebrate the feast wherever they happened to be.

4. For Moses tied the feast to the sacrifice and the sacrifice he tied to the most holy.

5. That the feast was taking place everywhere was not permitted by the sacrifice that was linked to it.

6. Moreover, that the sacrifice should be made everywhere was not permissible, as the sacrifice was tied down to the altar of the sanctuary.

7. The feast that was without sacrifice, was no feast the sacrifice without the sanctuary was never made.

8. If he (Moses) did not permit the people in their own land to celebrate the feast ouside Zion,

9. how is it possible for them in our day to celebrate the feast amongst the nations wherever they want to?

In this instance the argument from the lesser to the superior is again used. The antithesis coincides with the argument: in his own country :: amongst the nations; not outside Zion :: wherever he wants to. The norm appealed to in this instance is of course the Old Testament, a norm the Jews should have no difficulty in accepting. The double antithesis has the implication that the Jews are transgressing the rule, not in a doubled way but, so to speak, 'to the second power'. 
Later in this hymn, Ephrem explains that it is the prerogative of the Christians to partake of the Lord's supper wherever they would like to do so (vs 24-25). The Lord's supper is described as having substituted the feast that was supposed to have been celebrated in Jerusalem alone:

24. For instead of sacrifices of all kinds of animals made in Jerusalem alone,

25. the living body is sacrificed over the whole earth in our time - the living sacrifice.

By using a double antithesis on this critical point (all kinds of animals $::$ the living body; in Jerusalem alone $::$ all over the world) the contrast of particularism over against universalism is related to and used as an argument on a semiotical plane. The practice of the Jews in the time of Ephrem to celebrate the feast everywhere, creates a phased antithesis:

A Jews 'sacrifice' everywhere :: B not allowed to sacrifice everywhere \} C Practice contrary to Scripture

B Jews not allowed to sacrifice everywhere :: D Christians partake in Lord's supper everywhere $\}$ E Jews particularistic.

Of course assertion $\mathrm{A}$ and conclusion $\mathrm{E}$ are contradictions in a certain sense, but conclusions $C$ and $E$ both serve the polemic against the Jews. They don't follow their own rules, but even if they would do so, they would show in doing so that they have been replaced by the Christians.

\section{CONCLUSION}

From these examples, I believe, it becomes clear that arguments need not always be rational. There is not always a logical substructure that contributes to a convincing argument in the hymns of Ephrem. To hide these contradictory syllogisms, effective use is made of antitheses. The semiotic substructure of an antithesis contributes to make it an ideal figure of speech to implement in such cases.

In other instances, antitheses are put to a more noble use. In using the demarcating and defining quality of an antithesis, Ephrem strenghtens his arguments impressively.

Works cited

BALDINGER, K 1980. Semantic theory. Trans by Brown, WC. Ed by R Wright. Oxford: Blackwell. 
BARDENHEWER, O 1962. Geschichte der altkirchlichen Literatur, Band IV. Darmstadt: Wissenschaftlichen Buchgesellschaft.

BARKHUIZEN, JH 1985. Carmen Christianum: 'n Inleiding tot die Grieks-Christelike himnografie van die eerste ses eeue. Pretoria: NG Kerk Boekhandel.

BARKHUIZEN, JH 1986. Narrative apostrophe in the Kontakia of Romanos the Melodist with special reference to his hymn 'On Judas'. Acta Classica XXIX (19-27).

BOTHA, PJ 1982. Polemiese trekke in die Paasfeeshimnes van Afrem die Siriër, Unpublished MA-dissertation, University of Pretoria.

BYWATER, I 1946. De Poetica, in Ross 1946.

DUNCAN, EJ 1945. Baptism in the demonstrations of Aphraates the Persian sage. Washington: Catholic University Press.

FORSTER, ES 1946. De rhetorica ad Alexandrum, in Ross 1946.

HAEFELI, L 1932. Stilmittel bei Afrahat dem Persischen Weisen. Leipzig: Hinrichsshe.

HRUBY, K 1971. Juden und Judentum bei den Kirchenvätern. Zürich: Theologischer Verlag.

JAUSS, HJ 1982. Aesthetic experience and literary hermeneutics. Transl by M Shaw. Minneapolis: University of Minnesota.

KRAŚOVEC, J 1984. Antithetic structure in biblical Hebrew poetry. Leiden: Brill. (Suppl to Vetus Testamentum.)

KUMMER, I \& W 1976. Logic of action and the structure of practical arguments, in van Dijk, T (ed), Pragmatics of language and literature. Amsterdam: North-Holland.

LAUSBERG, H 1960. Handbuch der literarischen Rhetorik: Eine Grundlegung der Wissenschaft. München: Hueber.

NEUSNER, J 1968. A history of the Jews in Babylonia, Vol III: From Shapur l to Shapur II. Leiden: Brill.

NEUSNER, J 1971. Aphrahat and Judaism: The Christian-Jewish argument in fourth-century Iran. Leiden: Brill.

PELC, J 1971. Studies in logical semiotics of natural language. The Hague: Mouton.

PERELMAN, C 1979. The new rhetoric and the humanities: Essays on rhetoric and its applications. Dordrecht: Reidel.

ROBERTS, R 1946. Rhetorica, in Ross 1946.

ROSS, WD (ed) 1946. The works of Aristotle, Vol XI. Oxford: Clarendon.

ROSS, WD 1969. Aristotelis ars rhetorica, recognovit brevique adnotatione critica instruxit. Oxford: Oxford University Press.

SEGAL, JB 1970. Edessa 'the blessed city'. Oxford: Clarendon. 